Contents lists available at Journal Redwhitepress
Journal of Educational and Learning Studies
ISSN: 2655-2760 (Print) ISSN: 2655-2779 (Electronic)
Journal homepage: http://journal.redwhitepress.com/index.php/iles

\title{
The Effects of Self-Confidence and Social Support of Parents On Interpersonal Communication of Students
}

\author{
Dian Oktary ${ }^{1}$, Marjohan $^{2}$, Syahniar $^{3}$ \\ ${ }^{123}$ Universitas Negeri Padang
}

\begin{tabular}{l}
\hline Article Info \\
\hline Article history: \\
Received Nov $30^{\text {th }}, 2018$ \\
Revised Mar $28^{\text {th }}, 2019$ \\
Accepted Apr $11^{\text {th }}, 2019$ \\
\hline
\end{tabular}

\section{Keyword:}

Self-confidence

Parental Social Support

Interpersonal Communication

\begin{abstract}
This research is motivated by the problems students face regarding interpersonal communication in school. Self-confidence and parental social support are considered factors that could facilitate this problem. The purpose of this study therefore was to determine the extent to which self-confidence and social support of parents contribute to interpersonal communication. This study uses a descriptive correlational quantitative method and the population assessed were 73 students of SMP N 4 Batusangkarf selected by proportional stratified random sampling technique. The instruments used were selfconfidence, parental social support and interpersonal communication. Data was collected using the Likert scale model and analyzed using multiple regression method. The results show a significant (58.1\%) relationship between self-confidence and social support of parents with interpersonal communication.
\end{abstract}

(C) 2018 The Authors. Published by Redwhitepress

This is an open access article under the CC BY-NC-SA license

(https://creativecommons.org/licenses/by-nc-sa/4.0/

\section{Corresponding Author:}

Dian Oktary,

Universitas Negeri Padang

Email: oktarydian@gmail.com

\section{Introduction}

Humans as social beings are hardwired to make connections with one others and are unable to do everything alone. Most activity performed in his lifetime requires communication skills as seen in establishing relationships with other people. Unfortunately, not everyone is able to communicate well. For example, students with negative behaviors at school tend to lack this important ability. Some students are embarrassed and hesitant to express their opinions or ideas when asked questions. Others experience difficulties in developing friendships and social relationships. They also find it difficult to start a conversation with others.

According to Rakhmat (2003) people who lack confidence tend to avoid communication situations. Self-confidence also has an important role in meeting basic human needs such as happiness and success (Tuncel, 2015). In 2011, Devito stated that one of the characteristics of interpersonal communication is seen from individual self-confidence, while Clément and Kruidenier (2015) stated that self-confidence is an important element in communication.

In this study, parental social support was assessed from an individual perception. People who obtain good social support learn to behave well based on this treatment. They understand themselves and treat others better and this of course enhances the individual interpersonal communication. Conversely, individuals who have poor perceptions, tend to be closed in communication. They are difficult to work with and unable to understand themselves and others. This makes the individuals' interpersonal communication ineffective. 
According to the ecological theory of Bronfenbrenner (2003), family and the physical environment play an important role in child development.

People who attain effective support from their parents tend to portray better social characters. Hawari (1997) suggested that the way parents communicate with one another within the family affects what the child assimilates. Hence, the presence of good communication within the family serves as an example for children to learn how to communicate in a wider environment.

This study therefore aims to describe interpersonal communication skills of student, their selfconfidence, and parental social support. The effect of self-confidence and parents' social support on interpersonal communication was evaluated separately and together on students of SMP 4 Batusangkar.

\section{Method}

This study used a descriptive correlational quantitative method. The study population were students of class X, XI, and XII of the SMP 4 Batusangkar. Totaling 90 people, a sample of 73 people were selected with the proportional stratified random sampling technique and likert was the instrument used as the scale model. The level of reliability of the instruments of confidence, parental social support, and interpersonal communication were $0.723,0.922$ and 0.969 respectively, while the validity level of each instrument was $0.422,0.393$ and 0.675 . Data analysis was carried out with descriptive statistics, simple regression, and multiple regression. Data analysis was assisted by using the program SPSS 20.00 .

\section{Results and Discussions}

\section{Results}

\section{Self Confidence}

Table 1. Self-confidence data obtained from 73 respondents.

\begin{tabular}{|c|c|c|c|c|c|c|c|c|c|c|c|c|c|}
\hline & \multirow[t]{3}{*}{ Sub Variable } & \multicolumn{10}{|c|}{ Category } & \multicolumn{2}{|c|}{ Average } \\
\hline & & \multicolumn{2}{|c|}{ VH } & \multicolumn{2}{|l|}{$\mathbf{H}$} & \multicolumn{2}{|l|}{ M } & \multicolumn{2}{|l|}{$\mathbf{L}$} & \multicolumn{2}{|c|}{ VL } & \multirow[t]{2}{*}{$\%$} & \multirow[t]{2}{*}{ Category } \\
\hline & & $\mathbf{F}$ & $\%$ & $\mathbf{F}$ & $\%$ & $\mathbf{F}$ & $\%$ & $\mathbf{F}$ & $\%$ & $\mathbf{F}$ & $\%$ & & \\
\hline 1 & $\begin{array}{l}\text { Confidence in self- } \\
\text { ability }\end{array}$ & 4 & 5,5 & 33 & 45 & 36 & 49 & 0 & 0 & 0 & 0 & 70 & $\mathrm{H}$ \\
\hline 2 & Optimistic & 15 & 20,5 & 38 & 52,1 & 19 & 26 & 1 & 1,4 & 0 & 0 & 75,3 & $\mathrm{H}$ \\
\hline 3 & Responsible & 9 & 12,3 & 45 & 61,6 & 19 & 26 & 0 & 0 & 0 & 0 & 73 & $\mathrm{H}$ \\
\hline 4 & Objective & 13 & 17,8 & 36 & 49,3 & 22 & 30,1 & 2 & 2,7 & 0 & 0 & 74,2 & $\mathrm{H}$ \\
\hline \multirow[t]{2}{*}{5} & Rational & 29 & 39,7 & 31 & 42,5 & 10 & 13,7 & 2 & 18,8 & 1 & 1,4 & 79,5 & $\mathrm{H}$ \\
\hline & Whole & 8 & 11 & 43 & 60 & 22 & 30,1 & 0 & 0 & 0 & 0 & 73 & $\mathrm{H}$ \\
\hline
\end{tabular}

From the table, the average confidence level was high $(\mathrm{H})$ at $73 \%$. The acquisition of each subvariable of self-confidence in the total frequency of the very high (VH) categories was 8 at $11 \%$. The total acquisition of the high $(\mathrm{H})$ category is 43 with a percentage of $60 \%$. The total acquisition of the medium (M) category is 22 at $30.1 \%$. So in general, the confidence of student's is in the high category.

\section{Parents' Social Support Data}

Table 2. Parental social support data obtained from 73 respondents.

\begin{tabular}{|c|c|c|c|c|c|c|c|c|c|c|c|c|c|}
\hline & \multirow[t]{3}{*}{ Sub Variable } & \multicolumn{10}{|c|}{ Category } & \multicolumn{2}{|c|}{ Average } \\
\hline & & \multicolumn{2}{|l|}{ VH } & \multicolumn{2}{|l|}{$\mathbf{H}$} & \multicolumn{2}{|l|}{$\mathbf{M}$} & \multicolumn{2}{|l|}{$\mathbf{L}$} & \multicolumn{2}{|c|}{ VL } & \multirow[t]{2}{*}{$\%$} & \multirow[t]{2}{*}{ Category } \\
\hline & & $\mathbf{F}$ & $\%$ & $\mathbf{F}$ & $\%$ & $\mathbf{F}$ & $\%$ & $\mathbf{F}$ & $\%$ & F & $\%$ & & \\
\hline 1 & $\begin{array}{l}\text { Parent } \\
\text { Instrumental } \\
\text { Support }\end{array}$ & 47 & 64,4 & 22 & 30,1 & 4 & 5,5 & 0 & 0 & 0 & 0 & 86 & VH \\
\hline 2 & $\begin{array}{l}\text { Parent Emotional } \\
\text { Support }\end{array}$ & 49 & 67,1 & 20 & 27,3 & 4 & 5,5 & 0 & 0 & 0 & 0 & 87 & VH \\
\hline 3 & $\begin{array}{l}\text { Parent Information } \\
\text { Support }\end{array}$ & 59 & 81 & 14 & 19,2 & 0 & 0 & 0 & 0 & 0 & 0 & 90,9 & VH \\
\hline 4 & $\begin{array}{l}\text { Parent Award } \\
\text { Support }\end{array}$ & 50 & 68,5 & 22 & 30,1 & 1 & 1,4 & 0 & 0 & 0 & 0 & 88 & VH \\
\hline & Whole & 52 & 71,2 & 20 & 27,4 & 1 & 1,4 & 0 & 0 & 0 & 0 & 88 & VH \\
\hline
\end{tabular}

From table 2, the average parents social support is very high $(\mathrm{VH})$ at $88 \%$. The acquisition of each subvariable of parental social support within the very high $(\mathrm{VH})$ categories was 52 at71.2\%. The acquisition of the high $(\mathrm{H})$ category is 20 at $27.4 \%$. The total frequency of the medium $(\mathrm{M})$ category is 1 at $1.4 \%$. 
Interpersonal Communication

Table 3. Interpersonal communication data obtained from 73 respondents.

\begin{tabular}{|c|c|c|c|c|c|c|c|c|c|c|c|c|c|}
\hline & \multirow[t]{3}{*}{ Sub Variable } & \multicolumn{10}{|c|}{ Category } & \multicolumn{2}{|c|}{ Average } \\
\hline & & \multicolumn{2}{|c|}{ VG } & \multicolumn{2}{|l|}{ G } & \multicolumn{2}{|l|}{$\mathbf{M}$} & \multicolumn{2}{|l|}{$\mathbf{L}$} & \multicolumn{2}{|c|}{ LO } & \multirow[t]{2}{*}{$\%$} & \multirow[t]{2}{*}{ Category } \\
\hline & & $\mathbf{F}$ & $\%$ & $\mathbf{F}$ & $\%$ & $\mathbf{F}$ & $\%$ & $\mathbf{F}$ & $\%$ & $\mathbf{F}$ & $\%$ & & \\
\hline 1 & $\begin{array}{l}\text { There is a sense of } \\
\text { empathy }\end{array}$ & 9 & 12,3 & 43 & 60 & 21 & 29 & 0 & 0 & 0 & 0 & 73,3 & G \\
\hline 2 & Openness & 9 & 12,3 & 39 & 53,4 & 22 & 30,1 & 3 & 4,1 & 0 & 0 & 72,4 & G \\
\hline 3 & $\begin{array}{l}\text { Support the other } \\
\text { person }\end{array}$ & 17 & 23,3 & 31 & 42,5 & 22 & 30,1 & 0 & 0 & 0 & 0 & 71,8 & G \\
\hline 4 & Equality & 30 & 41,1 & 25 & 34,2 & 17 & 23,3 & 1 & 1,4 & 0 & 0 & 78,7 & G \\
\hline \multirow[t]{2}{*}{5} & $\begin{array}{l}\text { Positive attitude in } \\
\text { communication }\end{array}$ & 25 & 34,3 & 36 & 49,3 & 10 & 13,7 & 1 & 1,4 & 1 & 1,4 & 76,5 & G \\
\hline & Whole & 10 & 13,7 & 46 & 63 & 17 & 23,3 & 0 & 0 & 0 & 0 & 74 & G \\
\hline
\end{tabular}

From table 3, interpersonal communication was good (G) at $74 \%$. The acquisition of each sub-variable within the very good (VG) category was 10 at $13.7 \%$. The total respondents that ticked good (G) was 46 at $63 \%$. The respondents that ticked medium (M) was 17 at $23.3 \%$.

The contribution of Self Confidence to Interpersonal Communication, Parental Social Support to Interpersonal Communication, Self Confidence and Parental Social Support to Interpersonal Communication

Table 4. Results of simple linear regression analysis of self-confidence $\left(\mathrm{X}_{1}\right)$ to the interpersonal communication $(\mathrm{Y})$, Parental Social Support $\left(\mathrm{X}_{2}\right)$ of the Interpersonal Communication $(\mathrm{Y})$ and SelfConfidence $\left(\mathrm{X}_{1}\right)$ and Parental Social Support $\left(\mathrm{X}_{2}\right)$ of the Interpersonal Communication $(\mathrm{Y})$.

\begin{tabular}{|c|c|c|c|}
\hline NO & Variable & R & R Square \\
\hline $\mathbf{1}$ & $\mathrm{X}_{1}-\mathrm{Y}$ & 0.728 & 0.529 \\
\hline $\mathbf{2}$ & $\mathrm{X}_{2}-\mathrm{Y}$ & 0.569 & 0.324 \\
\hline $\mathbf{3}$ & $\mathrm{X}_{1}, \mathrm{X}_{2}-\mathrm{Y}$ & 0.763 & 0.581 \\
\hline
\end{tabular}

Based on Table 4, number 1 shows that the R-value of 0.728 portrays coefficient regression of self-confidence towards interpersonal communication. The 0.529 value of $\mathrm{R}$ square $\left(\mathrm{R}^{2}\right)$ depicts self-confidence contributing to interpersonal communication by $52.9 \%$, while the remaining $47.1 \%$ is influenced by other factors. Number 2 showed that the R-value of 0.569 indicates that there is regression coefficience with interpersonal communication. Then, the value of $\mathrm{R}$ Square $\left(\mathrm{R}^{2}\right)$ of 0.324 means that social support parents contribute to the interpersonal communication by $32.4 \%$. Number 3 shows that the R-value of 0.763 which indicates self confidence and parental social support has a significant contribution to interpersonal communication. Then $\mathrm{R}$ Square $\left(\mathrm{R}^{2}\right)$ value was 0.581 which means self-confidence and social support of parents contribute together to interpersonal communication by $58.1 \%$, while $41.9 \%$ is influenced by other factors not discussed in this study.

\section{Discussions}

\section{Self-confident students}

The research findings showed that on an average, students of SMP N 4 Batusangkar had high selfconfidence. Lauster (2002) describes five aspects that affect the individual's confidence as follows: confidence in self-ability, optimism, objectiveness, being responsible, rational and realistic. According to Pradita (2014), someone who does not have self-confidence, faces many challenges because self-confidence is an aspect of one's personality that serves to actualize the potential that they have. Therefore individuals with low selfconfidence are prevented from developing their abilities, which can be seen from their negative behavior. It is necessary to maintain the self-confidence that already exists in students and increase that of students who still lack it. This can be achieved through the impact of teachers, peers, parents and the entire environment community.

\section{Parental Social Support}

Research findings show that parental social support is in the very high category bacause they are the first environment students are exposed to. They teach various things including how to communicate with others. 
The role of parents in providing facilities, affection, attention, advice and information is needed to support children's development. According to Sarafino and Smith, (2011), someone who obtains social support believes that they are loved and cared for and valuable as they become part of social networks. The support that parents can provide include could be emotional this includes empathy, caring, and attention given by parents to children. It could be instrumental support, as in direct assistance that can be in the form of services, time and money. Parents also render information to their children. This includes their ability to address children's personal problems which include giving advice, guidance, suggestions, or feedback. They also offer support through friendship as expressed by the appreciation they give their children therefore they have the urge to move forward. Individuals who obtain good social support behave well based on the treatment they obtain. They also tend to understand themselves better and treat others well. The existence of social support provided by parents makes children feel loved. This has an impact on children's perceptions of what they obtain from parents. Besides that, support provided by parents such as providing information about communication skills gives kids a good example which eventually has an impact on their communication in the wider social environment.

\section{Student Interpersonal Communication}

This research shows that students' interpersonal communication is good. Relationships between individuals require communication and this is important in survival. Individuals who fail to connect interpersonally with others end up being rejected. Individuals who succeed in carrying out good and effective interpersonal communication on the other hand excel both in their social relationships and achievements. Prayitno (2006) stated that teens should show more affection, practice good listening and respect others. With good communication, individuals can effectively carry out their duties. This is in line with what Minarsih (2017) stated, that interpersonal communication is an important thing which influences the success of students in the future. Johnson (1995) shows several roles contributed by interpersonal communication in order to create happiness in human life, these include: Interpersonal communication helps intellectual and social development of individuals, It enables identity formation in individuals through communication with others, It improves understanding of reality and people also need to understanding how others perceive reality. To a large extent, mental health plays a part in the determination of the quality of communication and relationship with others. Interpersonal communication has an important role in supporting an individual's happiness and no matter how talented a person is, success will not be obtained without mastering effective communication skills.

\section{The contribution of Self Confidence to Interpersonal Communication}

The results of this study shows that self-confidence is significantly associated with variables of interpersonal communication, with a contribution of $72.8 \%$. That is to say, the higher the confidence the better the interpersonal communication. Conversely, if the confidence is low it results in low interpersonal communication (Sahputra, 2016). This finding was obtained based on a series of data analyzes which showed that self-confidence to a large extent contributes to interpersonal communication by $19.6 \%$. This is in line with the research conducted by (Siska, 2003). The feeling of inferiority, makes it difficult to communicate ideas and speak in public. It also makes them hesitate to air their thoughts in the mass media (Rakhmat 2003). People who are not confident tend to avoid communication situations. It can therefore de deducedthat self-confidence is one of the determining factors in interpersonal communication.

\section{Contributions of Parental Support to Interpersonal Communication}

The results showed that parental social support contributed significantly to interpersonal communication by $32.4 \%$ from the students perception. Individuals who are accepted and feel effective family functions, especially from their parents are perceived as such. Rakhmat (2003) explained that interpersonal behavior is very dependent on personal perceptions. A person's perception on the extent to which the environment satisfies or disappoints, influences their behavior in the environment. According to Desmita (2007), positive and supportive parental relationships allow adolescents to express positive feelings. This fosters social competency and also encourages autonomous responsibility. This means that the social support of parents plays an important role in the lives of students because, their behavior depends on how they perceive the social support given to them. It can therefore be concluded that a student's perception of parental social support are one of the factors that influence interpersonal communication. If it is positive, the interpersonal communication of the student ends up being better.

\section{The contribution of Self Confidence and Parental Social Support to Interpersonal Communication}

The results obtained from this study shows that self-confidence and parental social support together are significantly related to interpersonal communication. This indicates that confidence and social function of 
parents are major factors that contribute to interpersonal communication at a percentage of $52.9 \%$, while $41.9 \%$ is influenced by other factors not discussed in this study. Devito (2011) stated that individuals who have self-confidence donot exhibit anxiousness when communicating with others. Individuals who are socially selfconfident are relaxed, flexible and in control. Therefore, individuals who have self-confidence are easier to communicate with, they also have many friends. Success in any field cannot be achieved if people do not have self-confidence.

Kurniawati (2014) stated that families, especially parents are expected to care for each other and also provide care and support for their children. If all the support needed by students can be fulfilled, their perception of parental social support is also formed positively. This also affects their behavior and attitude. Good interpersonal communication will support an individual's social progess and an extended social interaction can be achieved. Interpersonal communication is good and smooth, if a message delivered can be received and understood in accordance with its contents and a direct feedback from the individual is received. In order for individuals to be able to communicate effectively, self-confidence is needed because selfconfidence is an expression of high esteem and belief in oneself.

\section{Conclusions}

Based on the findings and discussion, the following conclusions can be deduced: self confidence and parental social support together contribute significantly to the results of interpersonal communication in students of SMP 4 Batusangkar school.

\section{Suggestions}

It is recommended that parents provide support for children because they directly influence students. If all that is needed by students can be fulfilled, it affects the behavior, attitude and the interactive ability of a child which include interpersonal communication.

BK counselors are advised to include need assessment related to self-confidence In order to improve interpersonal communication amongst students. The basis for preparing BK service programs in schools is therefore to provide information services and group guidance. Efforts should be made to increase selfconfidence and parental social support. This improves interpersonal communication amongst students.

\section{Acknowledgments}

Acknowledge anyone who has helped you with the study, including: Researchers who supplied materials, reagents, or computer programs; anyone who helped with the writing or English, or offeredcritical comments about the content, or anyone who provided technical help. State why people have been acknowledged and ask their permission. Acknowledge sources of funding, including any grant or reference numbers. Please avoid apologize for doing a poor job of presenting the manuscript.

\section{References}

Astarini, D., Nirwana, H., \& Ahmad, R. (2016). Hubungan antara Konsep Diri Sosial , Persepsi Siswa tentang Dukungan Sosial Orangtua , dan Teman Sebaya dengan Komunikasi Interpersonal Siswa dan Implikasinya terhadap Pelayanan Bimbingan dan Konseling. Konselor, 5(4), 247-257.

Desmita. (2007). Psikologi Perkembangan. Bandung: Remaja Rosda Karya.

Devito, J. A. (2011). Komunikasi antar Manusia (Edisi Kelima). Terjemahan oleh Agus Maulana. Jakarta: Karisma Publishing Group.

Edwards, E., \& Roger, P. S. (2015). Seeking Out Challenges to Develop L2 Self-- $\square$ Confidence: A Language Learner's Journey to Proficiency. Tesl-Ej, 18(4), 1-24. Retrieved from http://tesl-ej.org/pdf/ej72/a3.pdf

Fithriyana, A. Dan Sugiharto, D. (2014). BimbinganKelompok dengan Teknik Permainan Simulasiuntuk Meningkatkan Kemampuan Komunikasi Antar Pribadi Siswa". Jurnal Mahasiswa Bimbingan Konseling,3 (2), pp: 138-142.

Hakim, T. (2002). Mengatasi Rasa Tidak Percaya Diri. Jakarta: Puspa Swara.

Hayrettin, T. C. EL. (2015). The relationship between self-confidence and learning Turkish as a foreign language. Educational Research and Reviews, 10(18), 2575-2589. https://doi.org/10.5897/ERR2015.2445

Lauster, P. (2002). Tes Keperibadian. (Alih Bahasa: D.H. Gulo). Edisi Bahasa Indonesia. Cetakan Ketiga belas. Jakarta: Bumi Aksara. 
Minarsih, Nirwana, H. (2017). Kontribusi Motivasi Menyelesaikan Masalah dan Komunikasi Interpersonal terhadap Strategi Pemecahan Masalah Siswa Sekolah Menengah, 3, 1-14.

Prayitno, E. (2006). Psikologi Perkembangan Remaja. Padang: Angkasa Raya.

Rakhmat, J. (2003). Psikologi Komunikasi. Bandung:RemajaRosdakarya.

Sahputra, D., Syahniar, S., \& Marjohan, M. (2016). Kontribusi Kepercayaan Diri dan Kecerdasan Emosi terhadap Komunikasi Interpersonal Siswa serta Implikasinya dalam Pelayanan Bimbingan dan Konseling. Konselor, 5(3), 182-193.

Santrock, J. W. (2003). Adolescence: Perkembangan Remaja. Terjemahanoleh Shinto dan Sherly Saragih. Jakarta: Erlangga.

Sarafino, E.P., and Smith, T. W. (2011). Health Psychology Biopsychosocial Interactions. Seventh Edition. Hoboken: Wiley.

Sarastika., P. (2014). Stop Minder dan Grogi: Saatnya Tampil Beda dan Percaya Diri. Yokyakarta: Araska.

Siska, S. \&Esti H. P. (2003). Kepercayaan Diri Dan Kecemasan Komunikasi Interpersonal Pada Mahasiswa. Jurnal Psikologi, 2(2), 67-71. https://doi.org/10.22146/JPSI.7025

Slameto. (2010). Belajar dan Faktor-Faktor yang Mempengaruhinya. Jakarta: Rineka Cipta.

Supratiknya. (1995). Komunikasi Antarpribadi Tinjauan Psikologis. Yogyakarta: Kanisius (Anggota IKAPI).

Afdal, A. (2015). Kolaboratif: Kerangka Kerja Konselor Masa Depan. Jurnal Konseling Dan Pendidikan, 3(2), 17.

Aldrich, N. J., \& Tenenbaum, H. R. (2006). Sadness, anger, and frustration: Gendered patterns in early adolescents' and their parents' emotion talk. Sex Roles, 55(11-12), 775-785.

Barends, M. S. (2004). Overcoming adversity: An investigation of the role of resilience constructs in the relationship between socio-economic and demographic factors and academic coping. University of the Western Cape.

Bengkuluekspress, B. (2018). Tempo 4 Bulan, 199 Kali Gempa. Bengkuluekspress. Bengkulu.

Bonanno, G. A., Galea, S., Bucciarelli, A., \& Vlahov, D. (2007). What predicts psychological resilience after disaster? The role of demographics, resources, and life stress. Journal of Consulting and Clinical Psychology, $75(5), 671$

Dinamika, Y. (2013). 12 Provinsi yang Ditetapkan jadi Daerah Rawan Tsunami. Banda Aceh: Serambi Indonesia.

Eisenberg, N., Valiente, C., Fabes, R. A., Smith, C. L., Reiser, M., Shepard, S. A., ... Cumberland, A. J. (2003). The relations of effortful control and ego control to children's resiliency and social functioning. Developmental Psychology, 39(4), 761.

Eliasa, E. I. (2011). Pentingnya Kelekatan Orangtua dalam Internal Working Model untuk pembentukan Karakter Anak (Kajian Berdasarkan Teori Kelekatan dari John Bowlby). Yogyakarta: Inti Media Yogyakarta Bekerjasama Dengan Pusat Studi Pendidikan Anak Usia Dini Lembaga Penelitian Universitas Negeri Yogyakarta.

Everall, R. D., Altrows, K. J., \& Paulson, B. L. (2006). Creating a future: A study of resilience in suicidal female adolescents. Journal of Counseling \& Development, 84(4), 461-470.

Grotberg, E. H. (1999). Tapping your inner strength: How to find the resilience to deal with anything. New Harbinger.

Haditono, S. R. (2004). Psikologi perkembangan pengantar dalam berbagai bagiannya. Yogyakarta: Gadjah Mada University Press, $N d$.

Handayani, P. G., \& Yuca, V. (2018). Fenomena Culture Shock Pada Mahasiswa Perantauan Tingkat 1 Universitas Negeri Padang. Jurnal Konseling Dan Pendidikan, 6(3), 198-204.

Hasgimianti, H., Nirwana, H., \& Daharnis, D. (2017). PERHATIAN ORANGTUA DAN MOTIVASI BELAJAR SISWA YANG BERLATAR BELAKANG MELAYU DAN JAWA. INSIGHT: Jurnal Bimbingan Dan Konseling, 6(2), 130-143.

Hetherington, E. M., Parke, R. D., \& Locke, V. O. (1999). Child psychology: A contemporary viewpoint. McGrawHill.

LaFromboise, T. D., Hoyt, D. R., Oliver, L., \& Whitbeck, L. B. (2006). Family, community, and school influences on resilience among American Indian adolescents in the upper Midwest. Journal of Community Psychology, 34(2), 193-209.

Laksono, P. M. (2009). PETA JALAN ANTROPOLOGI INDONESIA ABAD KEDUA PULUH SATU: MEMAHAMI INVISIBILITAS (BUDAYA) DI ERA GLOBALISASI.

Minangkabau, A. (2016). KALEIDOSKOP GEMPA BUMI SUMBAR : SEPANJANG TAHUN 2016 TELAH TERJADI 195 KALI. Pasbana.com. Sumatera Barat.

Mudjiran, M., \& Daharnis, D. (2010). Pemulihan Dini Mental Masyarakat Pasca Gempa di Kota Padang. Padang: Pemko Padang, BNPB, UNP.

Nirwana, H. (2003). Hubungan Tingkat Aspirasi dan Persepsi tentang Belajar dengan Hasil Belajar Matematika Siswa Sekolah Menengah Umum yang Berlatar Belakang Budaya Minangkabau dan Batak. 
Disertasi Tidak Diterbitkan. Malang: Program Studi Psikologi Pendidikan Pascasarjana UM.

Patterson, J. H. (2001). The Effectiveness of a Culture and Gender Specific Intervention for Increasing Resiliency Among African American Preadolescent Females. Childhood Education, 77(3), 182.

Pratiwi, R. P. (2007). Sumbangan Psikologi Klinis Dalam Assessment Gangguan Psikologi Mangsa Bencana Alam. Retrived November 28, 2011.

Prayitno, P. (2012). Jenis Layanan dan Kegiatan Pendukung Konseling. Padang: Universitas Negeri Padang (UNP) Press.

Reivich, K., \& Shatte, A. (2003). The resilience factor: 7 keys to finding your inner strength and overcoming life's hurdles. Harmony.

Santrock, J. W. (2007). Perkembangan anak. Jakarta: Erlangga.

Shibue, Y., \& Kasai, M. (2014). Relations between attachment, resilience, and Earned Security in Japanese University students. Psychological Reports, 115(1), 279-295.

Siebert, A. (2009). The Resiliency Advantage: Master Change, Thrive Under Pressure, and Bounce Back from Setbacks: Easyread Super Large 18pt Edition. ReadHowYouWant. com.

Stumblingbear-Riddle, G., \& Romans, J. S. C. (2012). Resilience among urban American Indian adolescents: exploration into the role of culture, self-esteem, subjective well-being, and social support. American Indian and Alaska Native Mental Health Research: The Journal of the National Center, 19(2), 1-19.

Sudirman, S., Daharnis, D., \& Marjohan, M. (2013). PERAN GURU BIMBINGAN DAN KONSELING SERTA PERAN GURU MATA PELAJARAN DALAM MENGATASI KESULITAN BELAJAR SISWA DI SEKOLAH MENENGAH ATAS (SMA) NEGERI. Konselor, 2(1). 